\title{
US environment projects may merge efforts
}

Washington. A planning team led by policy advisers in the White House is exploring ways of merging the current patchwork of US government environmental programmes into a single coordinated network for ecological research and monitoring.

The proposed network would go far beyond the problem-ridden Environmental Monitoring and Assessment Program (EMAP) sponsored by the Environmental Protection Agency (EPA), which has been scaled back in recent years (see Nature 374, 486 ; 1995). Instead, it would link dozens of government research projects ranging from water quality research to remote sensing.

The planning effort is being led by the National Science and Technology Council's Committee on Environment and Natural Resources (CENR), which has identified about 30 government programmes that spend roughly $\$ 500$ million a year on environmental monitoring and research.

These include the US Geological Survey's extensive network of stream gauges; surveys of breeding birds; monitors that test air quality for compliance with EPA regulations; Forest Service monitoring stations; and a network of 18 long-term ecological research (LTER) sites funded by the National Science Foundation.

According to Rosina Bierbaum, who took over recently as acting head of the CENR from Robert Watson on his move from the White House Office of Science and Technology Policy to the World Bank, there are also many non-federal programmes. "We're just beginning to barely understand what all the monitoring networks might be at the

regional or state or local level," she says.

At present, the networks gather information on different temporal and spatial scales, and their data exist in different formats. "There are a lot of things going on, but they are not well coordinated," says Watson.

The CENR invited scientists and resource managers working in a single region - the mid-Atlantic - to a workshop last month to begin building a conceptual framework for the integrated network. A second, national workshop is planned for

\section{IMAGE UNAVAILABLE FOR COPYRIGHT REASONS}

Chesapeake Bay: test-bed for new approaches to the collection of information on natural resources.

the summer. "We've already got a lot of the agencies thinking very hard about their monitoring systems and how to coordinate them better," says Bierbaum.

According to Watson, the first step is to identify what scientific questions need to be answered. He says the plan does not assume that more money will be available for environmental monitoring, but rather that the government can squeeze more value from its current $\$ 500$-million investment by

\section{'Indian ginseng' brings royalties for tribe}

New Delhi. An indigenous Indian tribe has been awarded the intellectual property rights to the active ingredient of a plant long known to it as helping to combat stress, in a move that the government hopes will help end the 'piracy' of tribal knowledge by both Indian and foreign drug companies.

The drug jeevani, which is based on this ingredient and is said also to provide an instant source of energy, has been developed from the plant Trichopus zeylnicus by the government-owned Tropical Botanical Garden and Research Institute (TBGRI) in Trivandrum, the capital of Kerala state.

After successful clinical trials, the institute has transferred the manufacturing know-how to Arya Vaidhya Pharmacy (AVP), a large manufacturer of ayurvedic drugs - drugs based on traditional Indian herbal medicines - for $\$ \mathbf{5 0 , 0 0 0}$.

The Kani tribe of the Agasthiyar hills in the southern state of Kerala will receive half of the know-how fee, and will also receive a share of a two per cent royalty on any future drug sales. This money will go towards 2,500 families of the Kani tribe who will cultivate and supply the plants to AVP at a price agreed with the TBGRI.

"The world did not know about this unique plant until the Kani people led us to it," says Palupu Pushpangadan, director of TBGRI. His institute started research on the plant seven years ago, after researchers noticed that the tribe members habitually ate its raw seeds before undertaking strenuous work.

Research at TBGRI concluded that the plant contained substances that stimulate the immune system. "Our jeevani acts like Chinese ginseng,"says Pushpangadan. "But it is superior, because it does not contain any steroid." Extensive trials of the herbal product were carried out on Indian athletes before the institute decided to market it.

A spokesman for the drug company, which plans to market jeevani internationally as a rival to ginseng, claims that it is a "money-spinner". K. S. Jayaraman making existing programmes more compatible with each other.

Many sites could probably be adapted or augmented to collect additional data. But, says Watson, "we almost certainly will need some new [monitoring] sites". The integrated network may take years to develop.

The EPA's EMAP programme, once viewed as a grand-scale nationwide ecological monitoring programme, would be part of the network. Robert Huggett, recently appointed chief of science at EPA - and a

critic of EMAP before taking his new job - is co-chair of CENR's team for creating the new integrated network.

Another agency to figure in the $z$ plan is the now disbanded National Biological Service (NBS), which by October will be reincarnated as the Biological Resources Division of the US Geological Survey, headed by a new 'chief biologist'. Ronald Pulliam, currently director of the NBS, says he is not interested in the job.

Persuading government agencies to work together will be the most difficult part of creating any integrated network. Watson says he does not foresee one agency taking charge of the programme. "As soon as you give an agency lead responsibility, all the other agencies walk away from it, or you end up with a war," he says.

Ensuring data compatibility among the various projects will be of paramount importance. Remote-sensing data, which will be flooding in from a whole new generation of Earth-orbiting satellites, will have to be made "user-friendly" to be of value to mainstream ecologists.

"A lot of thought needs to be given to exactly what [data] you try to store and how," says Gordon Orians of the University of Washington in Seattle, president of the Ecological Society of America. "There's a tremendous amount of hype on all this electronic [data] storage. But unless it's carefully done and there's a lot of quality control, I just don't think it will be used that much."

Nevertheless, Orians supports the CENR effort, and is cautiously optimistic it will succeed. James Gosz of the University of Mexico, who chairs the LTER executive committee and once headed the National Research Council panel that evaluated EMAP, also supports the idea of an integrated network. But, he says, "it's not going to be easy" when agencies feel their own programmes are being threatened.

Gosz believes the CENR planning workshops are the welcome beginning of a major government effort in wide-scale ecological monitoring. Such a coordinated research effort would be comparable to the Global Change Research Program, he says - "only bigger".

Tony Reichhardt 